УдК 398.8(=511.141)

DOI

\title{
ЮГАС КАТААIH
}

Аоктор габімітований, старший науковий співробітник Інституту етнографічних досліАжень Центру гуманітарних наук Угорської академії наук (Будапешт)

\section{JUHÁSZ KATALIN}

a habilitated doctor, adjunct senior research fellow at the Institute of Ethnology (Research Centre for the Humanities of the Hungarian Academy of Sciences)

\section{Бібліографічний опис:}

Югас, К. (2020) «Я відмиюся віА усіх моїх гріхів ... »: чистота й очищення в угорських народних піснях і баладах. Народна твориість та етнологія, 3 (385), 72-90.

Juhász, K. (2020) I Am Washing Myself of All My Ills... Cleanliness and Cleaning in Hungarian Folk Songs and Ballads. Folk Art and Ethnology, 3 (385), 72-90.

\section{«Я ВІДМИЮСЯ ВІД УСІХ МОЇХ ГРІХІВ...»: ЧИСТОТА Й ОЧИЩЕННЯ В УГОРСЬКИХ НАРОДНИХ ПІСНЯХ І БАЛАДАХ}

\author{
Анотація / Abstract
}

Між картиною світу, яку ми можемо отримати віА зафіксованих справжніх звичаїв та традицій, пов’язаних 3 очищенням, та існуючою фольклорною лірикою може бути суттєва різниця, оАнак у цих фундаментальних тенденціях можна виявити й певні подібності. Нас не має дивувати такий помітний акцент ролі жінки, оскільки в більшості культур турбота про чоловіка та сім'ю, тобто дотримання чистоти й охайності в родині та будинку, є однією 3 первісних традиційних жіночих ролей. ОАнак несподіваним $є$ те, що питання чистоти тіла (і загалом моральності), як це очікувалося в суспільстві, порушувалося виключно стосовно жінки. Чоловіки (та Аіти) не несли відповідальності за чистоту, а виключно їхні Аружини (матері).

Абсолютно в усіх зібраних мною польових АосліАженнях та зібраних віАомостях просліАковується цілком очевиАною в цьому контексті видатна роль жінок. Проте вона не була такою виразною, якою ії можна виявити в текстах народних пісень $\mathrm{i}$ балад. Поза всяким сумнівом, це відкриття можна вважати вельми красномовним, бо на моє переконання, фольклорні тексти завжАи містять сутнісні цінності та уявцення тої соціальної групи, яка їх створювала та використовувала.

1. Виходячи з того повідомлення, що містить текст, реальна дія майже ніколи не $є$ важливою; саме по собі миття й очищення здебільшого мають символічне значення.

2. Більшість текстів стосується ролі жінки в їхньому зв'язку з чистотою.

3. Є Аише кілька унікальних або дещо видозмінених «шаблонних» пісень, які стосуються символізму води в контексті чистоти.

Кмючові слова: угорська народна пісенність, фізична чистота, моральне очищення, жіночі повеАінкові ролі, символіка.

The difference between the picture that we can get from the actually recorded customs and traditions related to cleaning and from the folklore lyrics might be great, however the similarities can be detected in the fundamental tendencies. Such 
a remarkable emphasis of women's role is not surprising as in most cultures taking care of the husband and family, that is, keeping the family and house clean and neat is one of the primary traditional feminine roles. The surprising thing is, the purity of the body (and morale) as a social expectation was only raised in connection to women. The cleanliness of men (and children) is not their responsibility, but the wife's or mother's, who lives with them in the family.

All through the fieldwork and data collection process that I have done, women's outstanding role in this respect became quite obvious, but it was not as emphatic as it can be detected from the lyrics of folk songs and ballads. By all means, I think this discovery is very illuminating as I believe that folklore texts always incorporate the essence of the values and views of the social group which created and used them.

1. From the viewpoint of the message of the text the actual action is hardly ever important: the act of washing oneself and cleaning mostly carry a symbolic meaning.

2. The majority of the texts refer to women's role in connection with cleanliness.

3. There are only a few unique, or hardly modified «routine» songs that refer to the symbolism of water in relation to cleanness and purity.

Keywords: Hungarian folk songs, cleanliness, purification, female behavioral roles, symbolism.

ПовсякАенні звички АогАяАу за тілом, Аотримання чистоти - органічна скмадова способу життя мюАини. Аля цих звичаїв, як і Аля траАиційних народних обрядів, властиве формування таких форм поведінки і Аіяльності, «які утворилися в результаті спімьного проживання, тривалого часу, Усталимися з огляАу на повторення тих чи інших Аій; їхні оАноріАні форми стали суспільно прийнятними і перетворихися на частину траАиції [20, р. 402]. «АогляА» у вузькому сенсі означає таку суму Аій, які безпосеренньо спрямовані на очищення тіла й упоряАкування Аіючих норм. Обряди очищення і Аогляду за тілом Аемонструють тісний зв'язок 3 місцем особи й роАини, яке вони посіАають у системі суспікьної iєpapxiii.

Я АосліАжую селянські (сімьські) обряАи очищення з 1989 року [4] 1. ОАна з головних узагамьнених тез моїх стуАій: очищення - це не тривіа ьне позбавлення віА бруду. За Аопомогою очищення завжАи набувають якомога «чистішого» і Аосконалішого зовнішньо-

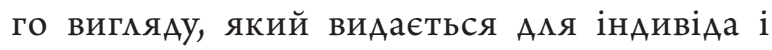
зовнішнього світу бажанішим, прийнятнішим. Саме цим, зовнішнім, виглядом засвіАчують, що, з огляду на смаки, морамь, характер та мислення Ааного індивіАа, він виступає як повноправний і оАноріАний (чистий) чмен важмивої Аля нього групи [4, р. 217].

Як професійна АосліАниця народних пісень, я завжАи зауважую, що той чи той текст пов'язаний з конкретною моєю науко- вою тематикою. ВіАтак я вирішила простежити, у якому контексті тематика чистоти й очищення виявАяється в нароАних піснях, тобто якою мірою тексти народних пісень корелюються з Ааними обряАами.

За основу АосліАження було обрано Аві репрезентативні антології текстів, що виявАяють найповніші тематичні групи угорських народних пісень і балаА у десятках тисяч прикмаАів 2, а також я прогмянула чудову збірку Яноша Берзе-НаАя, що містить 600 текстів. Окрім того, природно, вибрама з багатьох тисяч текстів відомі мені народні пісні й бамаАи, які анамізувама як ученийАосАіАник чистоти Упродовж останніх триАцяти років.

У текстах пісень і балаА ${ }^{3}$ воду згадано Аосить часто, а от миття, умивання, купання або чистоту - значно менше. 3 переглянутих мною багатьох тисяч текстів, пов'язаних із чистотою і очищенням, число проанамізованих фрагментів текстів - майже 200.

Природно, що в запропонованій невемикій праці я не маю змоги Аокманно розглянути цей неймовірно цікавий і багатогранний масив текстів, у якому чистота і купання, миття, умивання водою наявні в багатьох значеннях та контекстах. Окреслю мише головні тенденції.

В угорській (і не тільки угорській) семянській траАиції комплексна символіка воАи й чистоти вияв яється в системі звичаїв очищення, яка охоплює очищення тіла, АогмяА за тілом та ритуамьні очищення, спрямовані 
проти причинності (порча), а також мікувальні й профікактичні магічні та раціональні Аії. Водночас, розглянувши вищепоАану систему звичаїв з погляду фольк орних текстів, отримуємо мише мозаїчну картину, в якій окремі елементи постають акцентованими, а інші - заледве виявцяються. У віАібраному за конкретними, особцивими критеріями текстовому матеріалі поняття «чистота» і «акт очищення» фігурують у найрізноманітніших контекстах.

Переглянувши корпус текстів, одразу стверАжуємо, що, зважаючи на текстову інформацію, конкретна Аія нечасто важмива: акт очищення, позбавлення віА бруду зазвичай має символічний зміст. Упадає у вічі й те, що більшість пов'язаних із чистотою текстів стосується жіночої поведінкової ролі. Віднайдені мною мотиви можна поділити на Аві головні тематичні групи. Менша група Аотична до ритуальних тілесно-душевних Аій очищення, у якій мише кілька індивіАуальних (чи тільки в небагатьох збережених версіях) обрядових пісень містять символіку, пов'язану із чистотою воАи. Вони не будуть предметом Ааного досліАження ${ }^{4}$. Бікьшість текстів становить значний, пов'язаний із жіночими поведінковими ролями, корпус, у якому виокремлюємо піАтеми і розАіляємо їх на Аві великі групи, одна з яких (менша) Аотична до власне жінки, інша (більша) - Ао чменів РоАини.

\section{1. «ЧИСТА ЖІНКА»}

Очищення $є$ не мише Аією, спрямованою на позбавлення від фізичного або ритуамьного бруду, а водночас таке впорядкування (прикрашання) тіка і зовнішнього вигляАу, що АОзволяє АюАИні з'являтися в соціумі. Охайний зовнішній вигляА переАбачає укмаАання волосся віАповіАно Ао віку та сімейного статусу і гарний, чистий оАяг. Чистота в селянській системі цінностей (і у фольклоpi також) є очікуваною винятково стосовно жінки, а стосовно чоловіка, то загалом уважають, що Аля нього «достатньо бути трішки красивішим віА чорта». Виписаний у текстах народних пісень і балаА іАеал краси не деталізовано, а подано мише кілька його головних ознак (сереА них і чистоту), часто поряд з висміюванням протикежних рис. У згаАаній нижче пісні в чотирьох, 3 рефреном, строфах перераховано критеріі краси Аівчини. В останній строфі йдеться про тікесну красу:

Teli kertem zsályával, /

Szerelemnek langjával,

Gyönyörü violám, Gyönyörüszép rózsám!

A te szemed fekete, Azén szivem bélepte,

Gyönyörü violám, Gyönyörüszép rózsám!

Szemöldököd szivárván, A homlokod kömárvány, Gyönyörü violám, Gyönyörüszép rózsám!

Hajad le van eresztve /

Tested frissen feresztve.

Gyönyörü violám, Gyönyörüszép rózsám!

Мій садок повен шавлії, /

Полум'я кохання,

Моя чудова фіалко, моя прекрасна трояндо!

Твої очі чорні запали мені в серце,

Моя чудова фіалко, моя прекрасна трояндо!

Твої брови - веселка, чоло - мармур,

Моя чудова фіалко, моя прекрасна трояндо!

Твоє волосся розпущене, /

Тімо свіжовимите.

Моя чудова фіалко, моя прекрасна трояндо!

(край Секей, нині - Румунія)

[10/I, p. 203-204].

Красу часто символізують світла шкіра або білий колір оАягу, аАже праця, наАто в полі, забруднює вбрання, а піА палючим сонцем шкіра темнішає. Отже, біка шкіра, з одного боку, - це символ чистоти, а з Аругого, - вишуканість (звікьнення віА важкої праці).

Liliomszál a két karja, /

Nádmézből van az ajaka,

Képe rózsa, szája cukor, /

Szemöldöke selyemfodor. 
Твої руки - стебла мімеї, /

Уста - з очеретового меду,

Обличчя - троянаа, рот - цукор, /

Брови - шовкові хвимі

(с. ГаАьбатор, історична обл. Абауй-Торна)

[10/I, p. 203-204].

Világra termötté Gyönyörü szép angyal.

Szöbb a mosolygásod, Mint a piros hajnal.

Fehérebb a képed Fehér patyolatná,

Feketébb a szömöd fekete bogárná...

На світ тебе привів прекрасноликий янгол.

Твоя усмішка осяйніша віА рожевого світанку.

Твоє обличчя біліше віА білого батисту,

Твої очі чорніші від чорного жука...

(с. Сайас, історична обл. Торонтац) [10/I, p. 205].

Most akadtam egy csurgóra virágom, virágom, A csurgóban egy leányra virágom...

Kinek tejfehér az arca...

Szinaranyból van a lába...

Я зараз натрапив у Ажерелі на мою квітку,

У Ажерелі на Аівчину-квітку..

мою квітку,

У якої мичко біле, як молоко..

Із чистого золота їі ноги...

(край Мезьошег, регіон Молава, Румунія; текст відомий у багатьох інших місцевостях).

О́брази із цитованих текстів знаходимо і в значно Аавніших, зафіксованих у XVIXVIII ст., поетичних творах. ОАин $з$ улюбмених жанрів давньої угорської поезії преАставлено у творі «Adhortatio mulierum» («ПопереАження жінок»), у якому вимоги Ао жінок перераховано віА імені Аружки, родича, учителя, мандрівного поета, інко$\Lambda и$ - нареченого. В оАному разі - тон викмаАу серйозний, в іншому - жартівливий; незмінне єАине - вимоги завжАи висуває чоловік. Природно, що вірші-висміювання жінок, подані водночас із попереАженнями, АовоАять, що не кожна жінка сповнювала очікування:
Tiszta légy te fejér öltözetedben, Ne gyászoljad uradat még éltében.

Буаь чистою у своєму білому вбранні, Не носи жалоби за чоловіком за його життя.

Або інший вірш:

Ne járj, kérlek, szurkosan,

Viseld magad csinosan.

Не ходи, прошу тебе, засмамьцьована, Поводься гарно

(«3бірка пісень Сенчеї», 1704) [Аив.: 19].

У численних версіях пісні про парубка, який має намір одружитися, у рядках почергово показано можмивих обраниць, оАнак кожна має якусь ваду. Наприкінці, у розв'язці, пісні хлопець вирішив, що жоАна Аівчина не віАповіАає його вимогам, тому краще парубкувати Аалі. Як ваду селянської Аівчини в багатьох варіантах тексту названо ії неохайність:

Ha falusit veszek, hon nevelt, tudatlan

Es a csinossághoz rossz kedvü szokatlan, Semmi szép tréfa szót nem tud mordulatlan, Nem kap tisztaságon, rusnyán jár, mosdatlan.

Якщо я візьму із села (Аівчину), невиховану, неосвічену,

Ао її краси не пасуватиме поганий тон, ААже жоАного гарного жартівливого слова не мовить без грубощів, Не Абає про чистоту - ходить огиАна, немита

(Bocskor K. 1722, фолькморна версія м. Аєраьо, Румунія).

У висміюваннях Аівчат також часто трап-

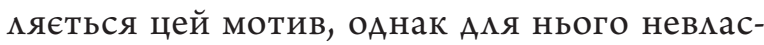
тиве детальне перерахування. Народна пісня характеризує неохайну, брудну Аівчину, як правико, одною чи Авома рисами:

Recik Náni retkös lába

Nem illik a kettös táncra...

Брудні ноги Нані Рецик

НеприАатні Аля парного танцю...

(м. Могач, обл. Бараня)

[2/I, p. 645]. 
Неохайна Аівчина не може бути гарною Аружиною:

Kiállitották a karót, be is állitották.

A lányoknak a javát is mind kiválogatták. Maradt nekem egy nagy boglyas, mit csináljak véle Kócot dugok az orrába, hadd ballagjon véle.

Виставими палі і знову забрали.

Більшість Аівчат уже порозбирали, А мені кишилася велика копиця.

Що ж маю $з$ нею робити?

Пакмі ій на носа - і так буде ходити

(с. Йошвафьо, історична обл. АбауйТорна)

[10/II, p. 579].

Що ж розуміють піА бажаною чистотою? Чистоту і спосіб очищення згінно із селянськими звичаями, про що знаходимо посилання в поетичних текстах. ПоряА зі звичними преАметами і взуттям найпоширенішими знаряААями Аотримання чистоти $\epsilon$ гребінець, мимо та жир Аля волосся, які, наприклаА, перераховані у жнивній пісні, що виникма в середовищі поденників:

Marokverö csongorádi lányok

Villát, bocskor itthon ne hagyjátok!

Fésüt, szappant, olajt is hozzatok,

Mert ha az nincs, jaj, de csúnyák vagytok!

Чонградські Аівчата, під час сінокосу

Вима, постоли вАома не залишайте!

Щітку, мило, олію також приносьте, Бо без цього всього, йой, які ви потворні!

$$
\begin{array}{r}
\text { (м. ЧонграА, обл. ЧонграА) } \\
\text { [10/II, p. 515]. }
\end{array}
$$

Змащення волосся жиром не випаАково практикували в цій суспільній групі, аАже в тимчасових, негігієнічних оселях мише в такий спосіб можна було вберегтися віА пеАикульозу. ВіАповіАно Ао запропонованих життєвих обставин жіночим іАеалом краси було пряме, гладенько зачесане та змащене (олією чи жиром) волосся. ОАнак ця мода в часи обуржуазнення поступово змінимася: у новостворених тогочасних піснях уже кучері були характеристикою красивої Аівчини.

Наприкінці XIX ст. змащення жиром волосся зазвичай практикували в середовищі груп з маргінесу суспільства - пастухів, розбійників, наймитів. ВіАтак, найімовірніше, як прикмаА небажаного, аніж обов'язкового, змащення волосся згаАано в цитованій нижче пастушій пісні. Зауважмо, що в Ааному випаАку йдеться не про «чисту» жінку, а про чоловіка із жирним волоссям, якого засуАжують уже більш цивілізоване село і місто (чи «світ»).

Zsírral kenem, zsírral kenem a hajamat

Jóba foglalom magamat

A hajamról lefoly a zsir,

Ez a világ rólam beszíl.

Жиром мащу, жиром мащу своє волосся -

Роблю себе гарнішим.

3 мого волосся стече жир,

Й увесь світ про мене заговорить

$[1$, p. 67].

Змащення жиром волосся в наступній

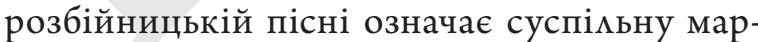
гінальність, відокремленість:

Hát a betyár hol eszi a vacsorát?

Zöd erdöbe süti a szalonnát.

Bal markába csöpögteti a zsírját,

Avva' kenyi fekete göndör haját.

I Aе ж опришок споживає свою вечерю?

У зеленому місі смажить сало.

Аівою рукою, по краплинах, збирає жир,

Аби ним намастити свої чорні кучері

$$
\begin{array}{r}
\text { (с. Банфа, обл. Бараня) } \\
\text { [2/I, p. 534]. }
\end{array}
$$

Бажаним кольором шкіри обличчя був Аещо червонуватий, помірно рум'яний віАтінок. Занадто блідий відтінок часто вважами ознакою хвороби, а креольський колір шкіри - ознакою поганих рис. Макіяж обличчя та інші практики Аогляду за шкірою часто пов'язували з моральною зіпсованістю, тому їх уникали. В Абані, наприкмаА, казали: «Обличчя тоді красиве, коли його нічим не мазюкають». Умивання, купання 
в молоці наводить на Аумку про мегендарної краси Клеопатру, яку в історії, головно через панські примхи, наслідувацо чимало жінок. Іштван Матюш у АовіАнику зі зАоров'я також згалав засіб із цімьного молока Аля усунення свербіння шкіри $[15$, р. 275]. Не забуваймо і про Аівчаток-пастушок із Сентгаця, які заАля краси шкіри обличчя іноді вмивамися овечим молоком або, частіше, сироваткою. У текстах народних пісень також описано вмивання молоком як засіб Аля Аосягнення бікого (свіжого) комьору обличчя:

Tejbe mosdik az én rózsám, ha fölkel,

Törülközik piros rózsalevéllel.

Fehérebb az orcája a fehér hónál,

Pirosabb is a hasadó hajnalnál.

Моя троянаа, прокинувшись, умивається

моцоком,

Утирається червоною пекюсткою троянаи.

Її обличчя біміше віА білого снігу,

Червоніше віА вранішньої зорі

$$
\begin{array}{r}
\text { (м. ЧонграА, обл. ЧонграА) } \\
\text { [10/I, p. 207]. }
\end{array}
$$

Буржуазні верстви села згодом почами використовувати, замість виготовменого вмасноруч, ароматизоване мимо, аптечний крем Аля обмиччя, ПуАру та помаАу. Починаючи з 1940-х років, раАше після війни, селянські Аівчата намагалися наслідувати ці кроки щодо Аогмяду за собою. Проте, зважаючи на брак коштів або іхню віАсутність, вони замінювами справжню фарбу якимись іншими фарбуючими речовинами. Креповий папір використовувами Аля піАрум'янювання обмиччя та уст, Аля піАмамьовування брів - кіпоть напівзгорілого сірника, але більшість-таки цурамася фарбувати обличчя. Різницю між семянськими i буржуазними цінностями наочно проілюстровано в таких народних піснях:

Nem kell nékünk maga büszke leánya; Egész héten a zongoráját nyomdossa! Mert minékünk dologra kell az asszony, Ne púderozza magát a kisasszony!
Нам не потрібна пихата Аівчина, Яка весь тижАень гратиме на піаніно! А нам потрібна жіночка до праці, Не варто їй пуаритися!

\section{(с. Терешке, обм. НограА;} із записів авторки, 2001).

Ha lepényem megettétek,

Sári lányom elvegyétek!

Nem köll nékünk a ke lánya,

Szölözsíros, pirosítós a pofája.

Якщо ви з'іми мій пиріг, -

Забирайте мою Аочку Шарі!

Нам не потрібна така Аівчина:

НапомаАжена, нарум’янена її пичка

(с. Госсугетень, обл. Бараня)

[2/I, p. 642].

У жартівцивій пісні також уміщено заувагу Аля Аівчат про першочерговість чистоти:

Palcsi Kata szép jány vóna Kata

Haja nyaka tiszta vóna Kata,

Mosd meg Kata a nyakadot,

Úgy pirosítsd ki magadot Kata!

Ката Палчі, Ката, була б вродиивою Аівчиною, Якби волосся, шия буми чистими в Кати.

Помий, Като, свою шию,

Як ти нарум’янимася, Като!

(м. МаАярпечка, історична обл. АраА, нині - Румунія)

$[10 / 1$, p. 552].

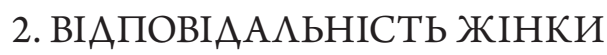

ЗА АОТРИМАННЯ ЧИСТОТИ

На всіх етапах кумьтурного розвитку суспімьства за Аотримання чистоти помешкання традиційно віАповіАама жінка. Саме на цій особливості наголошено в бімьшості фольклорних текстів. Сакральним обов'язком господині було прибирання хати і Авору, регулярне очищення вжиткових преАметів, миття, купання, а також піАготовка воАи Аля вмивання, розчісування волосся в Аітей і мітніх членів родини. Зазвичай вона 
допомагана Абати про чистоту і своєму чоловіку. У пісенній і баладній міриці прання, миття, розчісування волосся трапцяються в різних контекстах як символ материнської і подружньої турботи.

Аавніші фіксації цих пісень віднаходимо також у рукописних текстах XVI-XVII ст.:

Gyermekidet ékes erkölcsre tanitsd, Tüztül őrizd, az patakra ne taszitsd. Szeresd őket, ruhájokat megtisztitsd, Kérlek az fejeket meg ne koszositsd.

Своїх Аітей навчай суворій моралі, Оберігай віА вогню і не штовхай у воду.

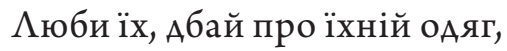
Прошу тебе, нехай їхні гомови

не забруднюються $[18, \text { p. } 47]^{5}$.

В уже згадуваному творі «Adhortatio mulierum» Аеякі закмикають Абати не мише про молоАь, а й про інших членів роАини:

Az mi házunkat te tisztán tartsad, Kicsin cellánkat gyakran megsöpörd, Mert ha házunkat rusnyául tartod, Ifjak, kik látják, csak megcsúfolnak, Tégödet mondanak: rusnya cundorának.

Нашу осемю тримай у чистоті, Часто підмітай їі, Бо якщо наш дім викмикатиме огиАу, Молодь, яка це побачить, буде тебе висміювати. Казатимуть тобі: «ГиАка нехлюя»

(6А. 1548 р., рукопис Аугошші) [22, p. 532-534].

ПоряА 3 текстами з поАібними інтенціями набагато частіше трапляються пісні (зАебільшого жартівливі), у яких висміяно неохайну, брудну жінку; відомі також і їхні фолькморизовані версії ${ }^{6}$. СереА них - жартівлива пісня $з$ початковим рядком «Я, Мішка, одружився», версії якої відомі по всій країні. У ній виявмені фізична занедбаність жінки з огмяду на спорадичне купання і забрудненість їі окремих частин тіка. Окрім того, неохайну жінку звинувачують у неАосвіАченості у виконанні Авох найважливіших (майже культових) жіночих робіт - у випіканні хліба і пранні. У Аеяких варіантах також відзначають недоліки в переробці молока або в чищенні посуду. Ось кише кілька віршів:

Megházasodtam, te Miska, /

Feleségem van, Anniska.

Tisztaságra elég tiszta, /

Kétszer seper egy holnapba.

A fejibe olyan tetü, /

Mint egy valóságos kescsü,

A szemibe olyan csapa, /

Mint egy hat koronás pipa.

Felkel regvel nyólc órakor, /

Feje olyan, mint egy bokor.

Az órrába olyan verö, /

Mint egy puliszka keverö.

Я, Мішка, одружився, /

Маю Аружину, Аннішку.

Щодо чистоти, то Аоволі охайна, - /

Авічі за завтрашній день замітала в хаті.

На голові така воша, /

Як справжня рукавиця,

У кутиках очей таке закиснення, /

Як мюлька за шість крон.

Устає рано, о восьмій гоАині, /

3 головою, як кущ.

На носі такі соп $\mathbf{i}$, /

Як перемішана мамацига

(с. Гьорбепатака, історичний регіон Чик, нині - Румунія; із зібрань 3. Камлоша,

Вочевидь у піснях мотив чистоти з'являється завЖАИ у зв'язку з конкретною проблемою. У піснях-насмішках проблемою $\epsilon$ погана Аружина, у пастуших, солдатських, батрацьких піснях - це брак Аружини чи турботливої жінки, але й досить мітній чоловік може бути обтяжливим Аля своєї Аружини. Розгляньмо кілька прикмадів на підтверАження вищеподаного узагацьнення.

ОАин зі словесних типів містить скарги чоловіків, які перебувають Аалеко віА Аому. У них часто йдеться про віАсутність жінки (матері чи Аружини) як симвоку турботи 
й опіки в побуті, в обов'язки якої передовсім входить прання. ВіАтак самотній чоловік стражАає віА бруду, якого може позбутися мише жінка.

Szennyes az én ingem, gatyám, /

Messze lakik édesanyám.

Nincsen fája, se hamuja, /

Hogy az ingem megszapulja.

Брудна моя сорочка, штани, /

Моя мати мешкає Аамеко.

Немає ні дерева, ні попеку, /

Щоб випрати мою сорочку.

$$
\begin{array}{r}
\text { (с. Загон, історичний край Гаромсек, } \\
\text { нині - Румунія) [10/II, p. 254]. }
\end{array}
$$

Szennyes ingem, szennyes gatyám,

Mezöségben lakik anyám.

Nincsen fája, se hamuja,

Hogy az ingem megszapulja.

Ne nézd, hogy én szennyes vagyok,

Mert szivemben nincsen mocsok

$A z$ az egy pecsét benne van:

Szeretlek én rózsám nagyon.

Брудна моя сорочка, брудні штани,

Моя мати мешкає в Мезьошезі.

$\mathrm{Hi} \mathrm{деревця,} \mathrm{ні} \mathrm{попеку,}$

Щоб випрати свою сорочку.

Не Аивися, що я брудний,

ОАнак у моєму серці немає бруду.

Мише одне в ньому закарбовано:

Я дуже кохаю тебе, моя трояндо

(секейський танок, віАомий у так званих танцювальних будинках Угорщини; секеї - субетнос угорців, які проживають у Румуніі).

Брудна сорочка рибалок також слугує Аоказом, що поряА немає жінки, яка $б$ турбувакася про них:

Hej, halászok, halászok, /

De szennyes a ruhátok.

Talán nincsen babátok, /

Aki mosna reátok.
Ой, рибамки, рибамки, /

Ну й брудні у вас оАяганки.

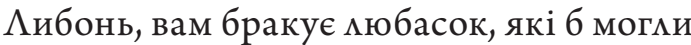
випрати пасок

(м. Годмезевашаргей, обл. ЧонграА)

[10/I, p. 252].

Вигнання, перебування Аалеко віА Аому, вівчарське життя - це таке «чоловіче» заняття, яке супроводжує постійне забруднення тіла й оАягу, і яке можливо змінити за Аопомогою жінки, наприклаА, шляхом оАруження.

Ingem, gatyám de szennyes, /

Magam vagyok tehenes

Ingem gatyám eladom, /

Magam megházasodom.

Ну й брудні моя сорочка, штани, /

Я пастух, череАник.

Продам сорочку, штани /

Та й оженюся

$$
\text { (с. ГерезАпуста, обл. Шомодь) }
$$

$[16$, p. 30].

ОАним 3 типових мотивів невільницьких пісень $є$ птах (пава або мелека), який приносить У Азьобі воду Аля купання. Пава в угорському фолькморі загалом постає у Авох контекстах. У невільницьких піснях, згіАно 3 християнськими уявленнями, вона - символ

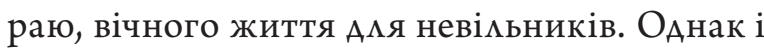
кохання часто також уявцяли в образі птаха. НаприклаА, це птах-вісник, тобто закохана Аівчина або наречена. Мелека, згідно 3 народними віруваннями, знає, Ае Ажеремо життя (звіАтіля приносить Ауші Аітей). Творення корелюється з водами - символом народження та віАродження (жіночий принцип); повертаючись як перелітний птах, воно означає віАродження природи. Таким чином, мотив птаха, що приносить воду Аля миття, також потрапив до багатьох жанрів, які зародилися в середовищі чоловіків робітників, вояків, котрі перебували Аалеко віА Аому в некомфортних аля себе умовах. $\prod_{A}$ час створення невімьницьких пісень віА- 
повіАні частини їх тексту були пристосовані Ао обставин військової чи сезонної робіт ${ }^{7}$. Варіант невольницької пісні:

Leszállott a páva /

Vármegyeházára.

Hozott egy kis vizet /

A rabok számára.

Mosdjatok meg rabok, /

Ne szomorkodjatok:

Kérjétek az Istent! /

Majd megszabadultok.

Сіка пава /

На буАинок обласної раАи.

Принеска трохи воАи /

Аля невільників.

Умивайтеся, невікьники, /

Не сумуйте.

Прохайте Бога! /

І згодом звіньнитеся

(с. Юта, обц. ШомоАь)

[10/II, p. 469].

Варіант солдатської пісні:

A nagy bécsi kaszárnyára rászállott egy gólya, Vizet hozott a szájába regruták számára.

Mosdjatok regruták, mert porosak vagytok!

Azt csak a Jóisten tudja, mikor szabadultok.

На велику віденську казарму зметів голуб,

Приніс воАи у Азьобі Аля рекрутів.

Умивайтеся, рекрути, бо ви запилюжені!

Тімьки Святий Бог знає, коли ви звіцьнитеся

(с. Барач, обл. Фейер) [10/II, p. 368].

Варіант жниварської пісні:

A mi házunk tetejére rászállott egy gólya,

Vizet hozott a szájába aratók számára.

Mosdózzatok meg aratók, mert porosak vagytok!

Úgyis a Jóisten tudja, mikor szabadultok.

На Аах нашого будинку сів мелека,

У Азьобі приніс воАи Аля женців.

Мийтеся женці, бо ви всі в пилові!

$\Lambda$ ише Бог знає, коли ви звільнитеся

(с. Кетгей, обц. ШомоАь)

[10/II, p. 522].
3 досвіду етнографічних експеАицій віАо-

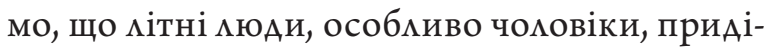
мяли менше уваги чистоті. ВіА осіб старшого віку і не очікували дотримання чистоти, навіть ставлення до цієї Аії було негативне. «Старому герб вже не Ао миця», - казаки, якщо ті наАто Абайливо АоГляАали за собою, прикрашалися чи понаА міру Абали про позахатній простір [3, p. 623]. Прикмадом вищевисловленого слугує народна пісня угорської

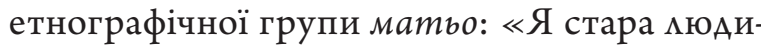
на, а не кавамер, / Тисне мою шию брудний комір сорочки».

У сув'язі 3 турботою Аружини про чистоту може виникнути пробцема зі значною різницею у віці, що виразно постає в баладному типі «старий чоловік». Аосі із цього ріАкісного типу ми зафіксувами мише кілька версій. Записана в Беді версія поєАнує в собі мотиви 3 низки банаА, сереА яких близький мотив Ао переказу про Синю Бороду - 3 Аійовою особою-спокусником жінок та володарем Аев'яти замків. У закмючних рялках цієі короткої історії, у стилі бамаАи, - бажання одружитися старого чоловіка пов'язане 3 браком чистоти, що супроводжує старість:

...Hanem azért vettelek el, /

Koszos fejem keresgetni, Koszos fejem keresgetni, /

Rühes hátam vakargatni.

...Тому я тебе і взяв /

Бруану голову чесати,

Бруану голову чесати, /

Коростяву спину чухати

$$
\begin{array}{r}
\text { (с. БеА, історична обл. Нітра, } \\
\text { нині - Словаччина) } \\
{[12, \text { р. 370]. }}
\end{array}
$$

Найдетамьніший текст балаАи 3 висвітАенням тематики чистоти містить версія 3 області Бараня:

Mer nem azé vettelek e /

Ifjak közé mulatozni,

Hanem azé vettelek e/

Én ősz fejem vadarászni! 
Puckos órom nyalogatni, /

Csipás szömöm szopogatni.

Бо не Аля того я з тобою оАружився, / Аби веселитися поміж молоді, А Аця того я з тобою оАружився, / Щоб у моїй сивій голові воші шукати! Шмаркатого носа облизувати, /

Гноєточиві очі смоктати

$$
\text { (с. Ержебет, обц. Бараня) }
$$

[2, p. 181].

Ще Араматичнішим є зображення вимушеного обов'язку Аотримання чистоти Аружиною в балаАах про змодіїв та розбійників. БамаАи містять загальнотиповий образ приниженої Аружини, яка пере оАяг чоловіка, заплямований кров'ю його жертв. НаприкмаА:

Férjhez adtál anyám hegyi tolvaj után.

A sok véres ruhát könnyeimmel mosom, Könnyeimmel mosom, bánattal sulykolom, Bánattal sulykolom, jajszóval szapulom. Ha reggel kimosom, délben bevérezi, Ha este kimosom, reggel bevérezi.

Ти мене, мати, віААала заміж за розбійника з гір. Запмямовану кровю одіж я перу своїми

сльозами,

Перу сльозами, тугою тру,

Тугою тру, зойками золю.

Як вранці поперу, - в обіА закривавиться,

Як увечері поперу, - вранці закривавиться

(с. Вайдакамараш, край Мезьошег, нині - Румунія) [8, p. 81];

Már én ha jóllaktam, jó regvel felkelni

Jó regvel felkelni, s az patakra menni.

$S$ az patakra menni, véres ruhát mosni.

Könnyüvel áztatni, jajszóval sulykolni...

Коми вже я гарно наїмся, то треба

буде рано встати.

Рано-вранці встати і піти до потічка.

Піти до потічка прати закривавлену сорочку. Змочувати її слізьми, йойканнями терти...

(с. Герлен, регіон МомАва, нині - Румунія).
У багатьох бамалах змочинець переА вирокомпросить свою кохану (або матір) випрати йому оАяг, забруАнений кровю. ЗАебільшого це прохання пророкує смерть розбійникові: воно скугує покаянням переА стратою і моральному, Ауховному очищенню, а також і його символізує. Шандор Ружа, найвідоміший угорський розбійник, у багатьох пісенних версіях пере А смертю звертається Ао матері:

Édesanyám, édesem /

Van-e ingem szennyesen?

Ha nincs ingem szennyesen, /

Küldök kettöt véresen.

Menjen le a Tiszára /

Menjen le a Tiszára

Mossa ki szép tisztára, /

A fia halálára.

- Моя матусю, моя солодка, /

Чи бруАна моя сорочка?

- Як сорочка не бруана, /

Принесу ще Аві закривавлені.

- Піни ао Тиси, /

ПіАи до Тиси,

Випери їі начисто, /

На смерть свого сина

(с. Вайдакамараш, край Мезьошег, нині Румунія [8, p. 281]; майже аналогічний текст: с. КьолкеА, обл. Бараня [2, р. 235]; Аив. також: с. Банфа, обл. Бараня [2, p. 285]).

Янчі Барна, який на прохання коханки вбив свою матір, просить Аочку випрати ОАЯГ:

...Véres lett a Barna Jani ruhája, Nincsen anyja, ki kimossa simára. Mosd ki babám a ruhámat fehérre, Holnap megyek csendbiztos úr elébe.

... Кривавим став одяг Яні Барни, Немає матері, яка випере його начисто.

Випери, Аитино, мій оАяг набіло, Завтра я стану переА паном урядником

(с. Буза, край Мезьошег, нині - Румунія) [8, p. 322]. 
СереА пісень немає як прикмаду тієї, що змальовувала 6 турботливу Аіяльність Аружини як іАимічну картину. Нижчезгадана пісня, у якій висміяно циган, з певного погляду $є$ винятком, водночас власне жанр чи те, як саме зображено етнічну групу, яку вважають найнеохайнішою, радше виявяя іронічне ставмення Ао Аійсності:

Kondor hajú feleségem /

A Jóisten adta nékem.

Azfog engem ébreszteni, /

Az fog engem megfésülni...

Моя кучерява Аружина, /

Її мені Аав Бог.

Вона буде мене будити, /

Буде мене причісувати...

(м. Совата, історична обл. Марош-Торда, нині - Румунія) [10/I, p. 617].

Як і в попередніх прикцадах, більшість текстів про материнську турботу про Аітей Аемонструють певну проблемну життєву ситуацію. Почнемо з винятково «безпробмемного» тексту. Не випадково, що саме в колисковій з'являється мати, яка Абає про чИстий ОАЯГ АИтини:

Tente, tente kisbaba /

Anyádnak sok a dolga:

Mos, ruhát szappanoz, /

Egykettöre kimossa,

Gyorsan ki is vasalja, /

A kötélre akasztja.

Mire felkel a baba, /

$\mathrm{Ki}$ is legyen vasalva.

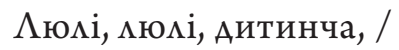

У твоєї матері багато роботи:

Пере оАяг мимом, /

Миттю віАпрала,

Швидко попрасуваца, /

Повісила на мотузку.

Коли прокинеться Аитина, - /

Буде все попрасоване

(с. НаАьрозваАь, історична обц. Земплен)

[10/I, p. 75];
Holnap az Úr napja lészen,

Nem lesz a ruhája készen (...)

Hogy ötöztetem szent fiamat,

Hófehérben Jézuskámat (...)

Mosni kezde, de hiába

Mosna könnyhullatásába,

Az eget felhö boritja,

Nem süt le a nap sugára a ruhájára.

Az eget sírva kéri,

A napot sírva kéri

Szüz Mária, hogy süssön ki. (...)

Eloszlott a bús felhö,

A nap szépen süt elö,

Szüz Mária kérésére

Szépen szárad öltözöje. (...)

Ezért mi is hálát adjunk,

Szombaton Szüz Máriát áldjuk.

Завтра буде Божий день,

Його оАіж не піАготовмена (...)

Аби вбрати мого святого сина,

Ісуса, у сніжно-біке (...)

Почала прання - та Аарма.

Випрала би слізьми, що м ються.

Небо затягнуми хмари,

Промені сонця не осяюють вбрання.

Пкачучи, благаю небо,

Пкачучи, бкагаю сонце,

Аіву Марію, аби осяяла (...)

Розвіялася сумна хмара,

Сонце гарно засяяно,

На прохання Аіви Марії

Його вбрання чудово висохло. (...)

Ми за це складаємо Аяку,

У суботу благословляємо Аіву Марію

(с. Аімеш, Трансимьванія, нині - Румунія).

У сув'язі з материнською турботою пробмемною ситуацією може стати непосимьна праця матері, яка має важку Аолю, жорстокість мачухи або скарга Аорослої мюАини у кризовий ї̈ періоА, котру знову огортає материнська турбота. Продемонструємо кімька прикмаАів щодо висловленого. 
У сповненому гіркоти тексті змальоване важке життя матері, яка самотужки виховує своїх дітей:

Édesanyám is volt nékem, Keservesen nevelt engem.

Ejszaka font, nappal mosott,

Jaj, de keservesen tartott.

У мене бума мати,

Важко їй було мене виховувати.

Вночі пряла, вдень мика,

Ох і гірко це їй Ааванося

(с. Мезьотаркань, обц. Гевеш) [10/II, p. 25].

В Угорщині відомо чимало текстових $\mathrm{i}$ мелодійних варіантів баладного типу про трьох сиріт. У більшості версій сироти скаржаться своїй мертвій матері на повеАінку мачухи:

Kelj föl, kelj föl édösanyánk, /

Mert elrongyollott a ruhánk.

Mosogasd ki ruháinkat /

Törülgesd mög fejeinket. (...)

Tova megyen egy menyecske, /

Két orcája ki van festve.

A'llesz néktek mostohátok, /

Ki gondot visel majd rátok

Mikor fejért ad reátok, /

Vérrel virágzik hátatok.

Mikor fejeteket mossa, /

Könnyüvel ázik orcátok

- Уставай, уставай, наша мюба матінко, /

Бо обшарпаний наш оАяг.

Випери наше вбрання, /

Вимий наші голови. (...)

- ...Іае молодиця до озера, /

Її щоки нафарбовані.

Вона стане вашою мачухою. /

Хто ж турбуватиметься про вас?

Коли голову наєте, /

Криваво цвітуть ваші спини.

Коми миє ваші голови, /

По ваших обличчях течуть сльози

(с. Торвай, обл. ШомоАь)

[12, p. 321].
У багатьох типах балад і народних пісень трапляється мотив, коли обдімений долею (або перебуваючи в критичній ситуації) головний герой говорить, що, мовмяв, краще 6 його мати не родила, не доглядала - купала, укривала, гойдаяа тощо, краще 6 він помер. Належний АогляА за дитиною, ії купання, що символізуе материнську турботу, в цих текстах обертається майже протилежністю, аАже виявляється марним і не захищає Аитину, яка стає на Аоросмий шлях життя, віА випробувань. НаприклаА, Ержі Сабо, мати-Аітовбивця, зітхає:

Anyám édesanyám, /

Mikor engem szültél,

Mikor engem szültél, /

Szültél volna követ!

Mikor feresztgetett /

Gyenge melegvízbe,

Mé nem feresztett vót /

Forró lobogóba!

Мамо, люба мамо, /

Коли ти мене народика,

Коли ти мене народила, /

То краще 6 народила камінь!

Коли ти мене клала /

У тиху тепцу воду,

Чому не покмана /

У памючий окріп?!

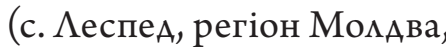
нині - Румунія) [8, p. 98].

\section{3. КУПАННЯ, МИТТЯ,}

УМИВАННЯ НЕ У ВОАІ

Загалом уважаємо природним, що (мильна) вода $\in$ основним засобом позбавлення віА бруду. ОАнак фізичної та ритуальної чистоти організму можна Аосягти за рахунок використання інших речовин (замість води чи оАночасно з нею). Прикмадів цього в історії чимало, ними послуговуються і нині [4, p. 117-120]. У контексті балаАних і міричних пісень розгляньмо мотиви, у яких замість води користуються іншими засобами позбавлення віА бруду. Щодо очищення без застосування води спадають на думку три метафоричні вирази: «купання в моло- 
ці-маслі », «купання у крові» та «купання у сльозах», які також містяться в бамалах і у сповнених гіркоти текстах, попукярних константних формулах. Перші Ава метафоричні вирази слугують умюбленими поетичними висловами повоАження.

Коми хтось «купається в молоці-маслі», У того буде щаслива Аоля. СтражАання новобранця і виданої заміжу чужу сторону Аівчини протиставлені м'якому віАношенню матеpi. Останнє означене виразом «купання в молоці-мас $\Lambda$ і»:

Édësanyám tëjbe-vajba /

Fürdëti a fiját,

Még húsz évet sëm töltött be, /

Katonának hijják.

Моя ріАна матір у молоці-маслі /

Купає свого сина,

Ще не сповнилося АваАцяти років, /

Як його забрахи в сомдати

(с. Цеказа, історична обм. Абауй-Торна) $[21$, p. 576].

У весільному привітанні родина нареченого обіцяє його обраниці щасливу Аолю в іхньому Аомі:

Örömanya ne bánkódjék (...)

Jó helyen van a leánya (...)

Tejbe-vajba fürösztgetik, /

Paplanos ágyba fektetik...

Мати нареченої не сумуватиме (...)

Ïї дочка в хорошому місці (...)

Купається в молоці-маслі, /

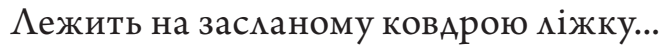

(с. Чикменашаг, регіон Чик) [10/I, p. 416].

У бамаАі про заможну жінку, яка не одразу впізнала в жебрачці свою матір, перша звертається Ао неї:

Jer bé mostan, mondom, jer bé, édösanyám, Tejbe megförösztlek, vajjal megkenetlek!.. Ne förössz ingömöt, ne keness ingömöt, Mert eleget kentél sötét tömlöcömben, Istenem, leányom, neköd fizessen meg.
- Тепер заходь, кажу, заходь, моя мамо, Я викупаю тебе в молоці, змащу маслом!.. Не чіпай сорочку, не бруАни мою сорочку, Бо Аосить ти бруАнима їі в темній в'язниці. - О ГосПоАИ, АОчКо, я віАПлачу тобі

[13, p. 19-21].

«Купання у крові - це симвом найбімьшої

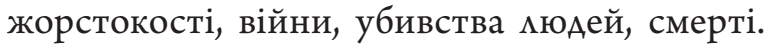
Кров постає як замінник воАи Аля миття у кращих бамаАних формулах прокмять: «Твоя вода Аля вмивання нехай перетвориться на кров, твій рушник нехай запамає вогнем!» («Анна Фегер», балала про Аівчину, яка пожертвувама цнотою залмя брата). Таким чином, після статевого акту Аівчина не пристає на спільну Аолю з насимьником. Вона заперечує саме те, що кожному чоловіку належить Аати Аружині - чисту воду, симвоц подружньої турботи в господарюванні.

0218

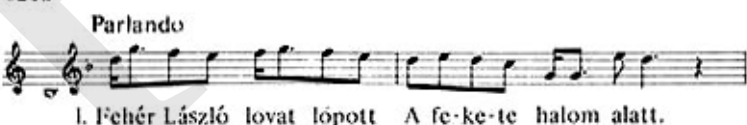

I. liehér László lovat lópott $\mathrm{A}$ fe-ke-te halom alatt.

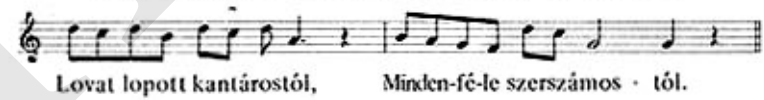

Hadnagy uram, hadnagy uram, /

Átkozott légy, hadnagy uram!

Mosdóvized vérré váljon, /

És a kendőd langot hányjon!

Törülköződ langot hányjon, /

Mindënëd hamuvá váljon!

Kíméletët ne találjon! /

$S$ tégëd Isten mëg ne áldjon!

Пане мейтенанте, пане мейтенанте, /

БуАь ти прокмятий, пане мейтенанте!

Воду Аля вмивання ти перетворюєш на кров, / І хустину жбурмяєш у вогонь!

Рушника жбурмяєш у вогонь, /

Все стає попелом!

Хай тобі не буде пощаАи! /

I тебе не благосмовить ГоспоАь!

(с. Іштеншегич, історичний край Буковина, нині - Румунія; с. Надьвейке, обц. Томна)

$[21$, p. 563]. 
«Купання у крові» - це вияв насил$\Lambda я$, неприродної смерті в баладах і піснях. Парубок через заборонене кохання вмирає віА смутку або стає самогубцем, що в балалах символізує занурення у криваву купімь:

Édös fijam gyüjj haza /

Édös fijam gyüjj haza

Nem megyök én ma haza, /

Nem megyök én ma haza,

Vérbe fürdök én még ma./

Vérbe fürdök én még ma.

- Аюбий сину, вертайся Аодому. /

$\Lambda$ юбий сину, вертайся Аодому.

- Я сьогодні не піАУ аодому. /

Я СьоГодні Не ПіАУ АОАОМУ.

Сьогодні я купаюся в крові. /

Сьогодні я купаюся в крові

(с. Ержебет, обц. Бараня)

[2/I, p. 256].

У баладі про затанцьовану до смерті Аівчину парубок закмикає музикантів:
Hújzátok cigányok /

Estétöl reggelig

Szegedi Mariska /

Míg vérben feredik!

Грайте, цигани, /

Звечора до рання,

Сегедська Марішка /

Уже в крові купається!

(с. Мадярчюгеш, регіон Чик, нині - Румунія) [8, p. 60].

Отже, «купання у крові» $є$ символічним виразом суму:

Minden napszentület elött /

Könnyembe' megmosdom elöbb

Mosdóvizre nincsen gondom, /

Mer' a könnyembe' megmosdom.

ПереА кожним божим Анем /

Я спершу вмиваюся слізьми.

Не бракує мені води Аля вмивання, /

Бо я вмиваюся слізьми

(с. Аімеш, Трансильванія, записано 3. Камлошем).

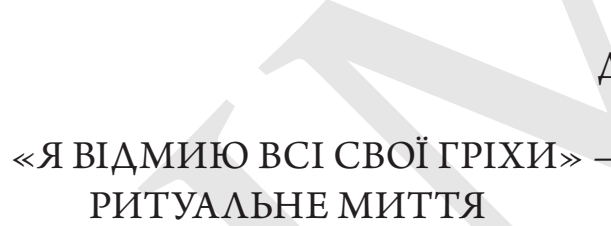

Árok árok, jaj, de széles árok

Oda járnak fürödni a lányok.

Édesanyám kimenek hozzájuk,

Fáj a szívem, meghasad utánuk.

Потоки, потоки, ой, та широкі потоки,

СюАи ходять КуПатися Аівчата.

Мамо, я піду до них,

Болить моє серце, розривається віА них

(с. Барач, обл. Фейер)

$[16$, p. 218].

Kiöntött a Tisza vize,

Szőke kislány fürdik benne.

Én is megfürödtem benn,

Rám is ragadt a szerelme.
Розмилися воАи Тиси,

Бікяве Аівча купається в них.

Я також викупався в річці,

Мене також охопимо кохання

$$
\begin{array}{r}
\text { (м. СегеА, обл. ЧонграА) } \\
\text { [10/I, p. 211]. }
\end{array}
$$

Folydogál, folydogál a szép Duna vize, Rajta mosakodik Piros szép Örzsébet... Rajta mossa rajta két szép fehér karját, Két szép fehér lábát, piros szép orcáját. Mindjárt ott mögfogta a fö török basa.

Тече, протікає вода прекрасного Аунаю, У ній купається чудова красна Ержебет... У ній миє, у ній, Авійко своїх біких рук, Авійко своїх білих ніг, чудове рожеве мичко. Ось-ось ї̈ схопить головний турецький паша (с. ПаАе, історична обц. Торонта $)$ [10/I, p. 151]. 
Guzsalyra se néze, /

Feredőhöz mene.

Nagyot es rikojta, /

Hogy mindenki hallja:

«Rabolják országod, /

Pusztitják népedet!»

Mindenki ellépe, /

Még rea se néze.

Dancia leánya /

Szépen megferede

Szépen megferede /

$S$ onnan visszatére.

Nem tudták kilelni /

Kegyesi mivoltát

Kegyesi mivoltát, /

Csak vitézi voltát.

На кужіль не Аивиться, /

ЙАучи Ао купальні.

Голосно заволана, /

Щоб кожен почув:

«Грабують твою країну, /

Знищують твій нароА!»

Усі віАступають, /

Не Аивмяться на неї.

Аочка Аанція /

Гарно викупамася,

Гарно викупалася /

Й звідтікя вернукася.

Не могми вони знати, /

Що вона, насправді, Аівчина,

Що вона Аівчина, /

А не витязь

(с. МеспеА, регіон МолАва, нині - Румунія) [8, p. 250].

Fehér liliomszál ugorj a Dunába

Támaszd meg oldalad két aranypálcába

Mosakodjál szépen az aranylavórból

Törölközzél szépen az aranytörlővel,

Fésülködjél szépen az aranyfésüvel

Imádkozzál szépen az aranyasztalnál...

Моя біка Аіліє, стрибай до Аунаю,

Обіприся на Аві золоті паці,

Гарненько вмивайся із золотої миски,
Гарненько утрися золотим рушником,

Гарненько розчешися золотою щіткою,

Гарненько помолися біля золотого столика...

Én felkelék jó regvel, hajnalban,

Kimosdódám minden büneimböl,

Megkendözém arany kendöcskével

Kimenék én ajtóm elejibe,

$S$ feltekinték nagy magos mennyégbe.

Nyitva látám mennyország kapuját,

$S$ azon belül mennyeknek ajtóját,

$S$ azon belül egy teritett asztalt,

$S$ azon vala egy rengö bölcsőcske.

Abba fekszik vala Urunk Jézus Krisztus,

Ül mellette vala anyánk Szüz Mária...

Я піднімаюся чудовим ранком, УАосвіта,

ВіАмиваюся віА усіх своїх гріхів,

Утираюся золотою хустинкою,

Стою біля Аверей

I Аивлюся в неозорі високі небеса.

Бачу відчиненими ворота раю

I там, усередині, - Авері небесні,

I там, усереАині, - накритий стік,

I там гойдається колисочка.

У ній межить наш Пан Бог Ісус Христос,

Поряа стоїть наша Мати Непорочна Аіва

Марія...

(с. МеспеА, регіон МолАва, нині - Румунія).

Ma van Húsvét napja, másod éjszakája, jól tudjátok

kinek első napján Jézus feltámadván dicsőséggel.

Lám, a madárkák is hangicsálnak, ök is

Szép plánták újulnak, termőfák vidulnak,

vigadoznak, virágoznak.

Máriska, Zsuzsánna, Rebeka, Borbála,

kegyes szüzek,

Keljetek fel ágyból, cifra nyoszolyából, mit alusztok!

Himes tojás légyen, tizenkét pár készen mi számunkra,

Ha pedig nem lészen, vízi puskám készen számotokra. 
Ha reátok lövök, ha reátok lövök, összeáztok!

Téli-nyári piszkot és az öszi mocskot mind

lemossuk.

Сьогодні день Пасхи, Аруга ніч,

ви добре знаєте,

Якого саме Аня славлять воскресаючого

Icyca.

Ну ось, і птахи теж щебечуть, вони теж

веселяться,

Чудові паростки схоАять, плоАючі дерева

радіють, розквітають.

Марішко, Жужанно, Ребеко, Борбало,

бкагочестиві незайманиці,

Уставайте з міжка, пишного можа, на

якому ви спами!

Хай будуть писанки, АванаАцять пар

підготовлено Аля вас,

А якщо не буде, моя поливальниця буде

піАготовцена Аця вас.

Якщо вАасться полити вас, Якщо полмю, -

ви змокнете!

Зимово-мітній бруА і осінню нечистоту всю змиємо

[11, p. 141-146].
Csütörtökön virradóra, Készül a lány a fonóba,

Kezét lábát mossa, jó megszappanozza

hogy ölegyen legszebb a fonóba.

Elvitte a viz a szappant,

Utána küldték a kappant,

Míg a kappan szállott, a szappan elázott

a folyóba.

Elmennék én tihozzátok,

De szemetes a szobátok.

Söpörd ki a házat, csókolom a szádat

Minden este.

У четвер, на світанні, Аівчина готується

Миє руки, ноги, гарно намилюється,

Щоб бути найкрасивішою на пряАках.

Вода понесла мимо,

За ним відіскали каплуна,

Аоки каплун метів, мимо розтануло в річці.

Я би пішов до вас,

Та брудні ваші кімнати.

Прибери в хаті, цікуватиму твого ротика

щовечора

(с. Бюкксек, обл. Гевеш, 51-річна жінка)

[21, p. 229].

\section{ВИСНОВКИ}

Проаналізувавши фольклорні тексти про чистоту й очищення, я намагалася, грунтуючись на змісті цих зразків, сформулювати символічне значення пісенних образів та міричних ситуацій. Звісно, що опрацьовані мною тексти я не вважаю правдивими Аокументами Аійсності. ОАнак погоджуюся 3 Іштваном Пациом-Аеменем, який висловився щодо певної інтерпретації символічних мотивів: «Наші пісні часто мише натякають, покиикаються на щось. За можиивістю, - і доволі часто, - виявляють себе як символи. Наука ці символи, на жаль, вивчає спорадично. Аеякі Аиметанти їх розуміють як алегорію, кожній частині надавши, тією чи іншою мірою, якомога обсценного значення. Натомість народні пісні є символічними, а символ саме тому є символом, бо не має простого, чітко окресленого сенсу; радше натякає, створює настрій; $є$ химерним; його значення часто загальне, іноді воно може змінюватися ${ }^{8}$. Водночас не вважаємо випаАковим, що хоч як віАрізняються ретельно задокументований матеріал обряАу очищення і мірична картина, що постає з фолькморних текстів, у кількох головних тенденціях таки можна знайти співпадіння. Значне піАкреслення жіночих ролей 
не Аивує, аАже в більшості культур сереА траАиційної жіночої Аіяльності на першому місці перебуває турбота про чоловіка, родину: утримання в чистоті членів сім'ї та оселі. Таким чином, охайність дорослого чоловіка - це не його турбота чи віАповіАальність, а жінки, яка живе 3 ним в одній родині або перебуває в Аушевному зв'язку (Аружина, матір, коханка). Це ж стосується й Аавньої угорської (семянської) культури. Аещо наштовхує на роздуми те, що тілесна (і моральна) чистота, як суспікьне очікування, формулювалася мише стосовно жінок, а у випадку чоловіків була сама собою зрозумілою або ж виключно обов’язком жінки. ПоряА із численними пісенними текстами, що висміюють неохайну, належним чином не Аоглянуту, жінку, постає іАеал «чистої жінки» (який, як правимо, символізує білий

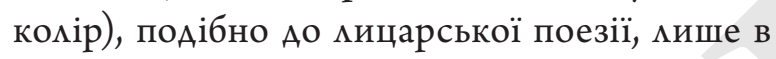
Аіричних картинах стосовно молодих (незайманих) Аівчат. Цей, «чистий», стан порушує саме чоловік [9, р. 24]. (Аодам мише, що побутують такі пісенні й балаАні сюжети, у яких дівчина купається, умивається і через це стає незахищеною перед чоловіком, який «псує» їі. ПриклаАом може слугувати балаАа про викрадену турками Аівчину, однак бамаАу в запропонованому досліАженні я не розгляАаю.) Заслуговує на увагу й те, що жінок, яких, згіАно $з$ траАиційним ритуальним трактуванням (через місячні й народження), уважають «нечистими» (чи, можмиво, саме тому?), саме вони здатні забезпечити всім чиенам родини тікесну чистоту і чистоту в середовищі проживання. Це, несправеАливе, суспільне розрізнення має давні культурно-історичні траАиції: у кожній культурі можемо виокремити таку (нижчого формування) суспільну групу, завданням якої $\epsilon$ позбавлення віА бруАу (вкАючаючи особисту гігієну), спричиненого особами, які перебувають на вершині соціальної драбини [9, p. 40-42]. ПіА час моїх польових робіт та збору Ааних про звичаї очищення було усвіАомлено визначну роль жінок у такому розподімі обов'язків, оАнак аж ніяк не з такими акцентами, як це подано в текстах Аіричних пісень і балаА. У будь-якому разі, я вважаю Аосягнутий результат повчальним, оскільки переконана, що фольклорні тексти, разом зі своєю символікою, завжАИ містять квінтесенцію цінностей та поглядів суспікьних груп, які їх формують і використовують.

\section{Примітки}

${ }^{1}$ СереА моїх численних праць, у запропонованому досліАженні я покликаюся мише на монографію за піАтримки фонду OTKA (Országos Tudományos Kutatási Alapprogramok - Основні Аержавні наукові досліАницькі програми) (Аив.: «Умивайся». Очищення в угорській народній традиції ХХ століття. Будапешт, 2006 [4]).

2 Авотомна праця «Magyar népdalok» («Угорські народні пісні») містить 2400 текстів, згрупованих за 47-ма пісенними типами [Аив.: 10], а «Magyar népballadák» («Угорські народні балади») - 300 текстів [Аив.: 12].

${ }^{3}$ І. Кюмльош розглядає символіку води в уснопоетичній творчості (Аив.: Тропи і символи. Конотація природних воА в угорських народних піснях і баладах. «Спільними зусияляи, суспільною свідомістю, у всіх на yстах : : фольклористичні праці. Будапешт, 2012 [14]).

${ }^{4}$ Більш розмогу мою працю 3 Ааної тематики див: «“Я змиваю все своє горе...”. Вода, очищення й чистота в угорських народних піснях і баладах [7].
${ }^{5}$ Інші варіанти тексту вміщено в таких рукописних книгах: «Komáromi énekeskönyv» («Книга пісень з Комарома») (1701), «Szentsey daloskönyv» («3бірка пісень Сенчеї») (1704), «Pál énekeskönyv» (1801 körül) («3бірка пісень Пама») (бл. 1801).

${ }^{6}$ Я їх цитую у своїй розмогішій праці [Аив.: 7].

7 Це твердження грунтоване на проведеному мною широкому аналізі залучених текстів американських шахтарських пісень (Аив.: Югас К. «Повага Ао гірничої галузі...». Пісні угорських гірників. Inde Aurum - Inde Vinum - Inde Salutem / упоряа. Я. Балі, А. Баті, Р. Кіш. Будапешт, 2010 [5]; Югас К. Народні пісні сереА угорських американців. Угорська спадщзина. Будапешт, 2010. Вип. 11: Угорські американці / реА. М. Гоппак [6]).

8 Іштвана Памма-Аеменя процитував I. Кюммьош [Аив.: 14, p. 544]. 


\section{Список використаних Ажерел}

1. Bencze L. Szivárványos az ég alja : Bihari népdalok. Berettyóújfalu : Bihari Múzeum, 1982.

2. Berze Nagy J. Baranyai magyar néphagyományok. Pécs : Baranya Vármegye Közönsége, 1940.

3. Jávor K. A magyar paraszti erkölcs és magatartás. Paládi-Kovács A. (föszerk.): Magyar néprajz. VIII. Társadalom. Budapest : Akadémiai Kiadó, 2000. P. 601-692.

4. Juhász K. Meg is mosakodjál. Magyar népi tisztálkodás a 20. században. Budapest : Timp, 2006.

5. Juhász K. «Tisztelet a bányász szaknak...» Magyarországi bányászdalok. Bali János - Báti Anikó - Kiss Réka Inde Aurum - Inde Vinum - Inde Salutem. Budapest : ELTE BTK Tárgyi Néprajzi Tanszék - MTA Néprajzi Kutatóintézet, 2010. P. 193-209.

6. Juhász K. Folksongs among the AmericanHungarians. Hoppál Mihály (szerk.): Hungarian-Americans (Hungarian Heritage 11). Budapest : Európai Folklór Intézet, 2010. P. 61-78.

7. Juhász K. «I am washing myself of all my ills...». Water, cleaning, and cleanliness in Hungarian folk songs and ballads. URL : https://mta.academia.edu/ KJuh\%C3\%A1sz.

8. Kallós Z. Balladák könyve. Budapest : Magyar Helikon, 1977.

9. Kapitány Á., Kapitány G. Néhány gondolat a tisztaság szimbolikájáról. Juhász K. (szerk.). Tiszta sorok. Tanulmányok a tisztaságról és a tisztálkodásról. (Documentatio Ethnographica 25). Budapest : L'Harmattan, Angyalföldi Helytörténeti Gyüjtemény, MTA Néprajzi Kutatóintézete, 2009.

10. Katona I., Ortutay Gy. Magyar népdalok. Budapest : Szépirodalmi Kiadó, 1975.
11. Kerényi Gy. (szerk.): A Magyar Népzene Tára II. Jeles napok. Budapest : Akadémiai Kiadó, 1953.

12. Kríza I., Ortutay Gy. Magyar népballadák. Budapest : Szépirodalmi Kiadó, 1976.

13. Kriza J. Vadrózsák. Székely népköltési gyüjtemény I-II. (Magyar népköltési gyüjtemény. XI). Budapest : Atheneaum, 1911.

14. Küllős I. Szóképek és jelképek. Természetes vizeink konnotációja a magyar népdalokban és balladákban. Közkézen, közszájon, köztudatban. Folklorisztikai tanulmányok. Budapest : Akadémiai Kiadó, 2012. P. 543564.

15. Mátyus I. A jó egészség megtartásának módjáról [válogatás, utószó és jegyzetek. Szlatky M.]. Budapest : Magvető, 1989.

16. Pesovár F. Béres vagyok, béres. Fejér megyei népzene. Székesfehérvár : István király Múzeum, 1982.

17. Rajeczky B. (szerk.). Hungarian Folk Music 3. (LPX 1805-53). Budapest : Hungaroton, 1982.

18. RMKT: Régi Magyar Költők Tára. XVII. 3. Szerelmi és lakodalmi versek (szerk. Stoll B., Klaniczay T.). Budapest : MTA Irodalomtudományi Intézet, 1961.

19. Szilágyi M. Adhortatio mulierum a Szentseydaloskönyvben és a Mahábháratában. 2006. URL : http:// indiahangja.blog.hu/2006/06/07/adhortatio_mulierum (letöltve 2010.07.15).

20. Verebélyi K. Szokás. Voigt V. (szerk.): A magyar folklór. Budapest : Osiris Kiadó,1998. P. 400-450.

21. Vargyas L. A magyarság népzenéje. Budapest : Zenemükiadó, 1981.

22. Varjas B. Szombatos énekek. Budapest : Akadémiai Kiadó, 1979.

\section{References}

1. BENCZE, Lászlóné. Szivárványos az ég alja: Bihari népdalok [The Bottom of the Sky is Rainbow: Bihari Folk Songs]. Berettyóújfalu: Bihari Múzeum [Museum of Bihar], 1982 [in Hungarian].

2. BERZE NAGY, János. Baranyai magyar néphagyományok [Hungarian Folk Traditions of Baranya]. Pécs: Baranya Vármegye Közönsége [Baranya County's Audience], 1940 [in Hungarian].

3. JÁVOR, Kata. A magyar paraszti erkölcs és magatartás [The Hungarian Peasant Morality and Behavior]. In: Attila PALÁDI-KOVÁCS (ed.-in-chief). Magyar Néprajz. VIII. Társadalom [The Hungarian Ethnography. Vol. VIII: Society]. Budapest : Akadémiai Kiadó [Academic Publisher], 2000, pp. 601-692 [in Hungarian].

4. JUHÁSZ, Katalin. Meg is mosakodjál: Magyar népi tisztálkodás a 20. században [You Should Wash Yourself. The Hungarian Folk Cleaning Customs in the 20th Century]. Budapest: Timp K., 2006 [in Hungarian].
5. JUHÁSZ, Katalin. «Tisztelet a bányász szaknak ... » Magyarországi bányászdalok [«Respect for the Mining Industry...» Songs of Hungarian Miners]. In: János BALI, Anikó BÁTI, Réka KISS, eds., Inde Aurum Inde Vinum - Inde Salutem. Budapest: ELTE BTK Tárgyi Néprajzi Tanszék - MTA Néprajzi Kutatóintézet [Ethnography Department (Eötvös Loránd University) \& Ethnographic Research Institute of the Hungarian Academy of Sciences Publishers], 2010a, pp. 193-209 [in Hungarian].

6. JUHÁSZ, Katalin. Folksongs among the AmericanHungarians. In: Mihály HOPPÁL, Katalin JUHÁSZ, Hanga GEBAUER, eds., Hungarian-Americans (Hungarian Heritage 11). Budapest: Európai Folklór Intézet [European Folklore Institute Publishers], 2010b, pp. 61-78 [in English].

7. JUHÁSZ, Katalin. «I am Washing Myself of All My Ills....» Water, Cleaning, and Cleanliness in Hungarian Folk 
Songs and Ballads [online]. Available at: https://mta.academia.edu/KJuhász [in English].

8. KALLÓS, Zoltán. Balladák könyve [The Book of Ballads]. Budapest: Magyar Helikon [Hungarian Helicon], 1977 [in Hungarian].

9. KAPITÁNY, Ágnes, Gábor KAPITÁNY. Néhány gondolat a tisztaság szimbolikájáról [Some Thoughts on the Symbolism of Purity]. In: Katalin JUHÁSZ, ed., Tiszta sorok. Tanulmányok a tisztaságról és a tisztálkodásról. (Documentatio Ethnographica 25) [Clean Lines. Studies on the Cleanliness and Cleansing. (Documentatio Ethnographica 25)]. Budapest: L'Harmattan, Angyalföldi Helytörténeti Gyüjtemény [Angyalföld Local History Collection], MTA Néprajzi Kutatóintézete [Ethnographic Research Institute of the Hungarian Academy of Sciences], 2009 [in Hungarian].

10. KATONA, Imre, Gyula ORTUTAY. Magyar népdalok [Hungarian Folk Songs]. Budapest: Szépirodalmi Kiadó [Belles-Lettres Publisher], 1975 [in Hungarian].

11. KERÉNYI, György. (ed.). A Magyar Népzene Tára II. Jeles napok [The Collection of Hungarian Folk Music II: Good days]. Budapest: Akadémiai Kiadó [Academic Publisher], 1953, pp. 141-142 [in Hungarian].

12. KRÍZA, Ildikó, Gyula ORTUTAY. Magyar népballadák [Hungarian Folk Ballads]. Budapest: Szépirodalmi Kiadó [Belles-Lettres Publisher], 1976 [in Hungarian].

13. KRIZA, János. Vadrózsák. Székely népköltési gyüjtemény I-II [Wild Roses. Szeklers' Folk Poetry Collection, Vols. I-II]. (Magyar népköltési gyüjtemény. XI) [Hungarian Folk Poetry Collection. Vol. XI]. Budapest: Atheneaum, 1911 [in Hungarian].

14. KÜLLŐS, Imola. Szóképek és jelképek. Természetes vizeink konnotációja a magyar népdalokban és balladákban) [Word Images and Symbols. The Connotation of Our Natural Waters in Hungarian Folk Songs and Ballads]. In: Imola KÜLLŐS. Közkézen, közszájon, köztudatban. Folklorisztikai tanulmányok [In Public Hands, in Public Speech, in the Public Consciousness. Folklore Studies]. Budapest:
Akadémiai Kiadó [Academic Publisher], 2012, pp. 543564 [in Hungarian].

15. MÁTYUS, István. A jó egészség megtartásának módjáról [válogatás, utószó és jegyzetek. Szlatky M.] [On How to Maintain Good Health]. Compiled, prefaced and annotated by Mária SZLATKY. Budapest: Magvető [The Sower], 1989 [in Hungarian].

16. PESOVÁR, Ferenc. Béres vagyok, béres. Fejér megyei népzene [I'm Hired, Hired. Folk Music of Fejér County]. Székesfehérvár: István király Múzeum [King Stephen Museum Publishers], 1982 [in Hungarian].

17. RAJECZKY, Benjámin (ed.). Hungarian Folk Music 3. (LPX 1805-53). Budapest: Hungaroton, 1982 [in English].

18. KLANICZAY, Tibor, Béla STOLL (eds.). RMKT: Régi Magyar Költók Tára. XVII. 3. Szerelmi és lakodalmi versek (szerk. Stoll B., Klaniczay T.) [The Library of Old Hungarian Poets. Vol. XVII. Ch. 3: Love and Wedding Poems (edited by B. Stoll and T. Klaniczay)]. Budapest: MTA Irodalomtudományi Intézet [Institute of Literary Studies of the Hungarian Academy of Sciences Publishers], 1961 [in Hungarian].

19. SZILÁGYI, Márta. Adhortatio mulierum a Szentsey-daloskönyvben és a Mahábháratában. 2006 [Adhortatio mulierum in the Szentsey Songbook and the Mahabharata. 2006] (online). Available at: http://indiahangja.blog. $\mathrm{hu} / 2006 / 06 / 07 /$ adhortatio_mulierum (downloaded on 2010.07.15) [in Hungarian].

20. VEREBÉLYI, Kincső. Szokás [Habit]. In: Vilmos VOIGT, ed., A magyar folklór [The Hungarian Folklore]. Budapest: Osiris Kiadó [Osiris Publisher], 1998, pp. 400450 [in Hungarian].

21. VARGYAS, Lajos. A magyarság népzenéje [The Hungarian Folk Music]. Budapest: Zeneműkiadó [Music Publisher], 1981 [in Hungarian].

22. VARJAS, Béla. Szombatos énekek [Saturday Songs]. Budapest: Akadémiai Kiadó [Academic Publisher], 1979 [in Hungarian].

Переклала з угорської Цеся Мушкетик 


\section{Do 125 -річного ювілею Marcuma Ruabcbrozo}

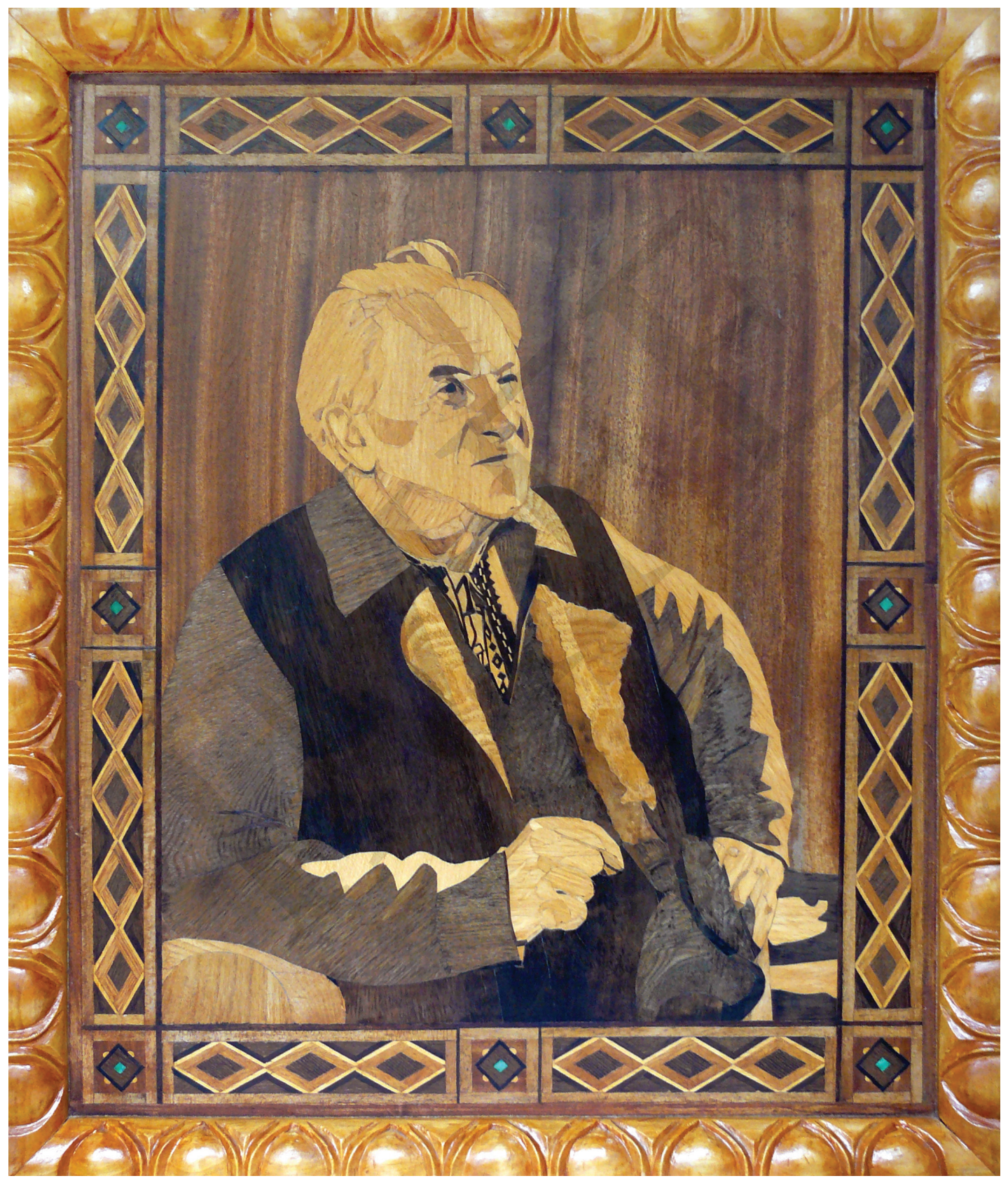

Л. Зущик. Портрет М. Рильського.

$1982 \mathrm{p}$. 

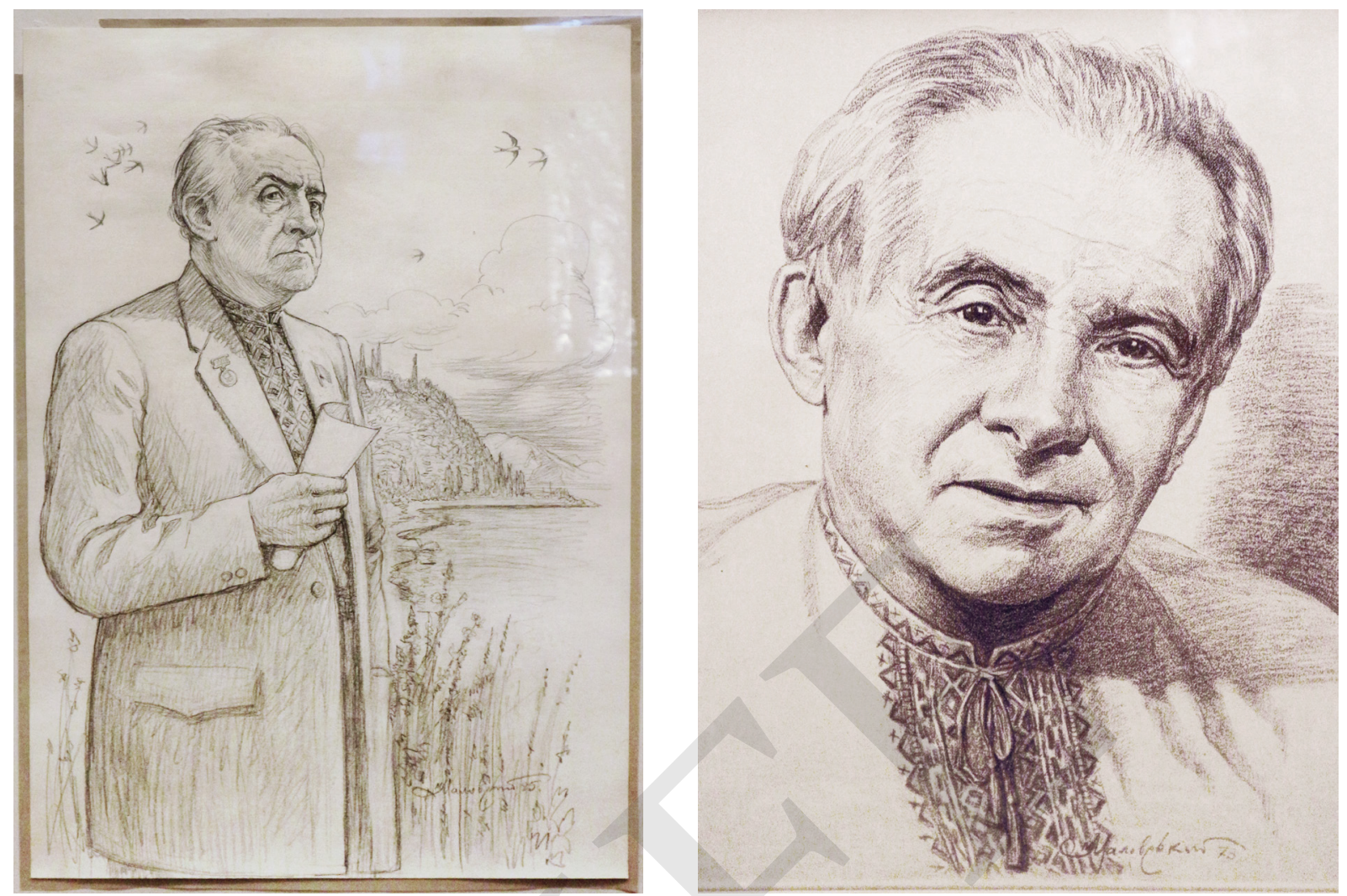

М. Маловський. 1 - «Максим Рильський біля Тарасової гори». 1985 р. Папір, олівець. 2 - портрет М. Рильського. 1973р. Папір, олівець. Архів Літературно-меморіального музею Максима Рильського

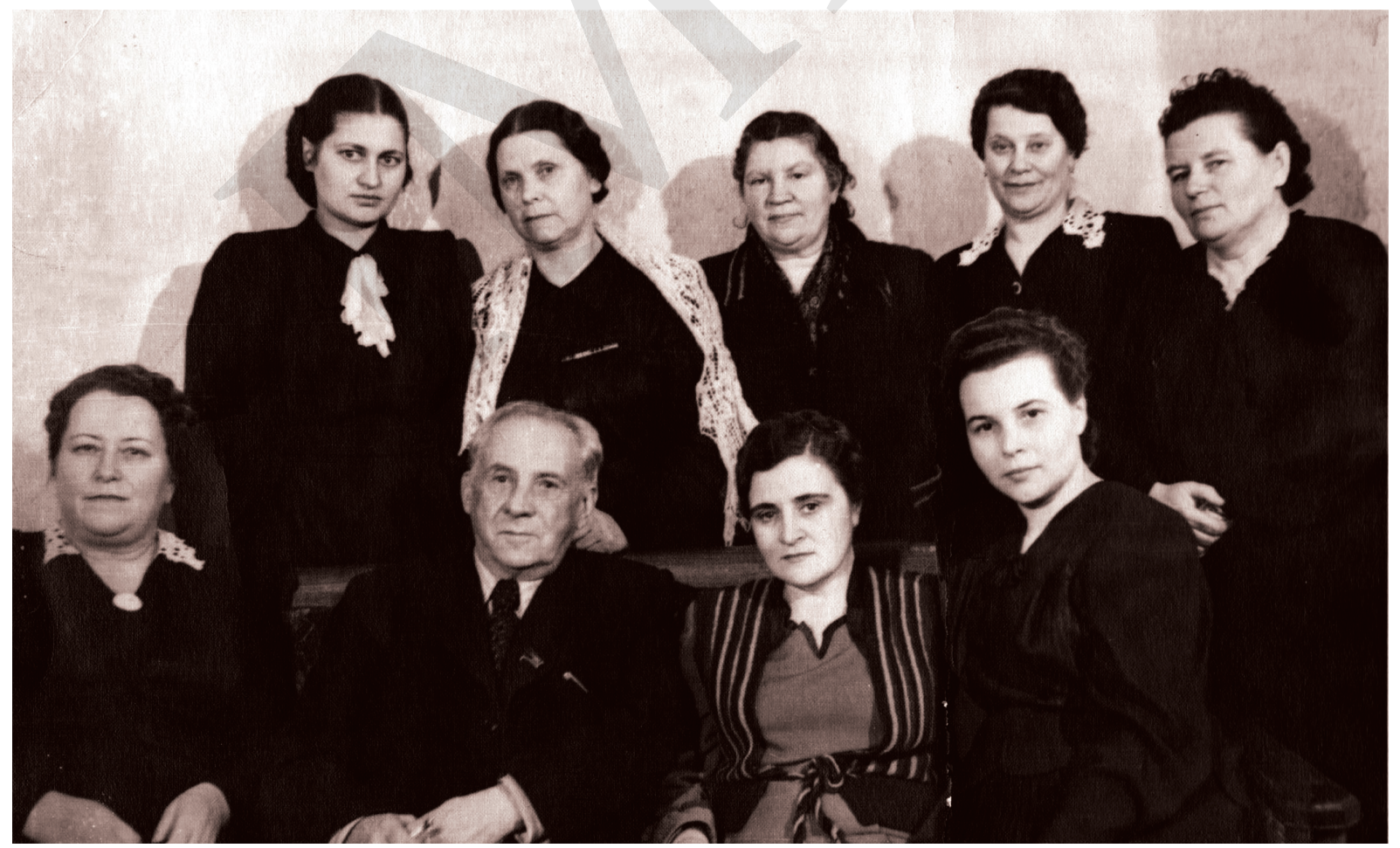

Під час святкування 60-річчя М. Рильського.

Нижній ряд: В. Бобкова, М. Рильський, Г. Сухобрус, В. Хоменко.

Верхній ряд: Г. Рубай, М. Родіна, О. Маркіянова, О. Чікіна, М. Ліждвой 

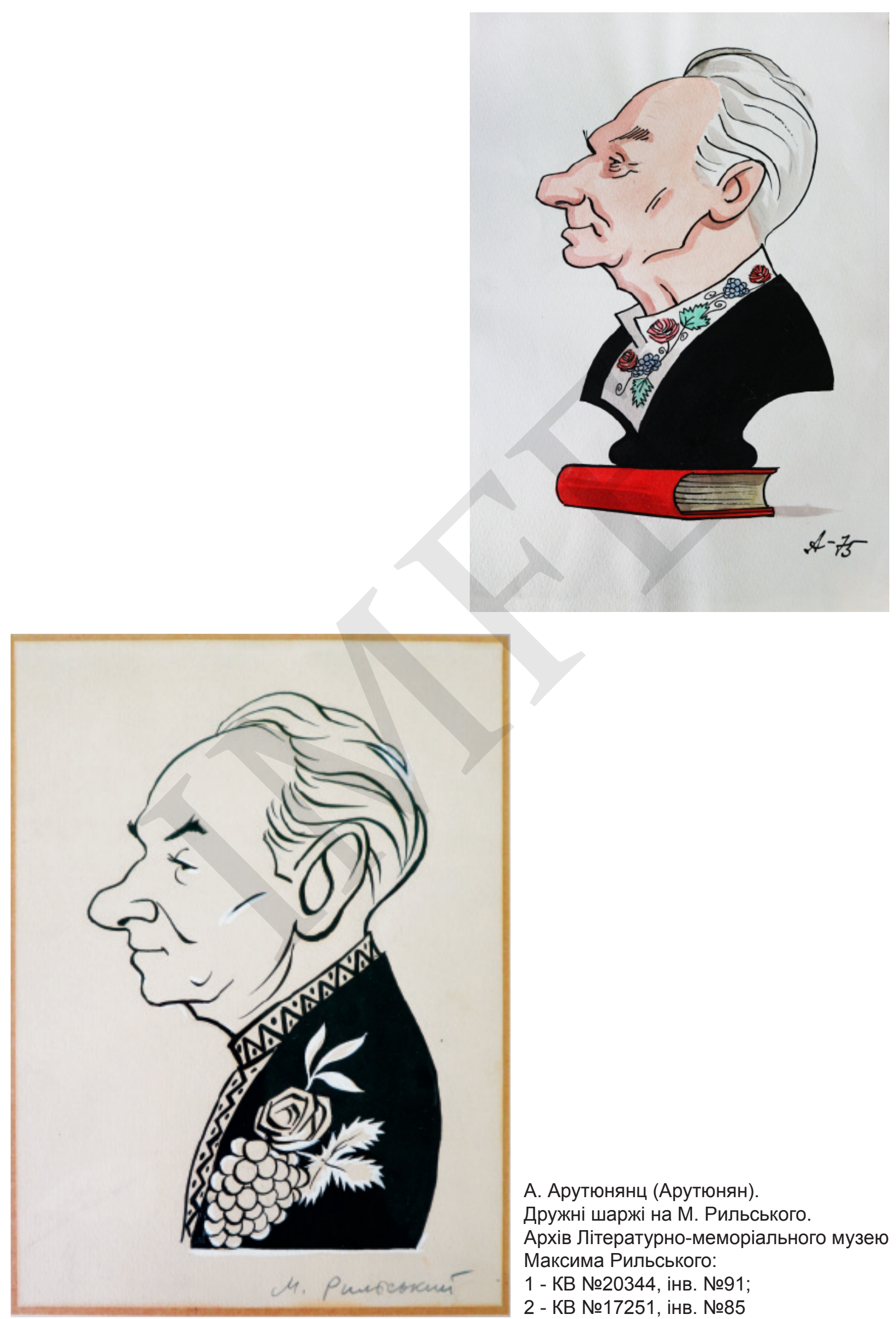

А. Арутюнянц (Арутюнян).

Дружні шаржі на М. Рильського.

Архів Літературно-меморіального музею Максима Рильського:

1 - КВ №20344, інв. №91;

2 - КВ №17251, інв. №85 